\title{
Delimitation of the genera Katapsuxis, Cnidiocarpa and Selinum (Umbelliferae) and the taxonomical synopsis
}

\author{
T. A. Ostroumova, E. V. Kljuykov, T. V. Lavrova, U. A. Ukrainskaja \\ Botanical Garden of Biological Department of Lomonosov Moscow State University, Leninskie Gory, 12, Moscow, 119991, \\ RussianFederation.E-mails: ostro_t_a@mail.ru,kljuykov@gmail.com,lavrovamgu@mail.ru,ulja_ukr@mail.ru
}

Keywords: anatomy, Apiaceae, morphology, synonyms, synopsis, systematics, taxonomic characters.

Summary. In recent decades the circumscriptions of genera Cnidiocarpa, Katapsuxis and Selinum have been repeatedly revised. The nomenclature of these genera is connected with Cnidium and Ligusticum. The morphology, anatomy and micromorphology of fruits, and the morphology of leaf segments of all species of the genera Cnidiocarpa, Katapsuxis, Selinum, as well as Cnidium monnieri and Ligusticum scoticum have been studied in detail. The exocarp cells of Katapsuxis silaifolia have conical projections and papillae with a striato-knotted and rugulate surface. The fruits of Ligusticum scoticum are covered with large convex cells with a rugulate cuticle. The Cnidium monnieri fruits are covered by a continuous scabrous wax layer that masks cuticular foldings. In other species, the boundaries of the cells are indistinct or visible only on some areas of the surface, the cuticle is striate and rugulate, and wax is absent. On the basis of the obtained observations and previously published molecular phylogenetic studies, Cnidiocarpa, Katapsuxis and Selinum were shown to be separate genera, substantially distant from the type species of Cnidium and Ligusticum. Keys have been compiled to identify the abovementioned genera, their species, and (in the case of Katapsuxis silaifolia) varieties, the synonyms are listed, and distribution data are given. The most important diagnostic features are the micromorphology of the fruit surface, the shape and dissection of the leaf segments, the shape of the leaf sheaths, the shape of the stylopodia, the length of the styles, and the secretory ducts number.

\section{Таксономический конспект и разграничение родов Katapsuxis, Cnidiocarpa и Selinum (Umbelliferae)}

\author{
Т. А. Остроумова, Е. В. Клюйков, Т. В. Лаврова, У. А. Украинская
}

Ботанический сад Биологического факультета Московского государственного университета им. М. В. Ломоносова, Ленинские Горы, 12, г. Москва, 119991, Россия

Ключевые слова: анатомия, зонтичные, конспект, морфология, синонимы, систематика, таксономические признаки.

Аннотация. Объем родов Cnidiocarpa, Katapsuxis и Selinum в последние десятилетия неоднократно пересматривался. Номенклатура этих родов связана с Cnidium и Ligusticum. Подробно изучена морфология, анатомия и микроморфология плодов, морфология листовых сегментов всех видов родов Cnidiocarpa, Katapsuxis, Selinum, а также Cnidium monnieri и Ligusticum scoticum. Клетки экзокарпа Katapsuxis silaifolia несут конические бугорки и папиллы со струйчато-узловатой и морщинистой поверхностью, плоды Ligusticum scoticum покрыты крупными выпуклыми клетками с морщинистой кутикулой, на плодах Cnidium monnieri отмечен сплошной шероховатый слой воска, скрывающий рисунок кутикулы; у остальных видов границы клеток неразличимы или видны лишь на некоторых участках поверхности, кутикула струйчатая и морщинистая, воск отсутствует. На основании полученных наблюдений и опубликованных ранее молекулярно-филогенетических исследований показана самостоятельность родов Cnidiocarpa, Katapsuxis и Selinum, а также их значительные 
отличия от типовых видов родов Cnidium и Ligusticum. Составлены ключи для определения указанных родов, их видов и (в случае Katapsuxis silaifolia) разновидностей, приведены основные синонимы, данные о распространении. Определены важнейшие диагностические признаки - микроморфология поверхности плода, форма и рассечение сегментов листа, форма листовых влагалищ, форма подстолбиев, длина стилодиев, число секреторных канальцев.

\section{Introduction}

Rafinesque (1840) described the genus Katapsuxis Raf. on the base of Ligusticum cicutaefolium Vill. He did not give a description of the new genus and only noted the difference from Ligusticum L.: "92, Katapsuxis Raf. diff. Ligust. petals inflexed, seeds ovate sulcate, involucre none, involucels polyph. linear - type $K$. cicutefolia $\mathrm{R}$. Laserp. do Villars, flowers white. 93, Ligusticum L. types L. levisticum, scoticum, balearicum, peregrinum, with yellow flowers, seed ovate acum. 5-costate, inv. and involucels polyph.” (pp. 58-59). This idea was not accepted by his contemporaries, and the name of this genus was forgotten for a long time. Ligusticum cicutaefolium has proved to be a later synonym of Laserpitium silaifolium Jacq. The type species of Katapsuxis is now known in floristic literature as Cnidium silaifolium (Jacq.) Simonk. (Simonkai, 1886; Halacsy, 1901; Tutin et al., 1968; Hedge, Lamond, 1972; Pimenov, Leonov, 1993) or Selinum silaifolium (Jacq.) Beck (Beck, 1927; Leute, 1970; Heller, Heyn, 1993). The closely related taxa $C$. orientale Boiss. and $C$. reichenbachii Huter ex Pichler were regarded as separate species (Pichler, 1881; Schischkin, 1950; Mouterde, 1970; Hedge, Lamond, 1972), or were included in $C$. silaifolium in the rank of subspecies or varieties (Halacsy, 1901; Hayek, 1927; Tutin, 1968; Leute, 1970; Ostroumouva, 2018), or C. orientale was regarded as a synonym of Selinum silaifolium and C. reichenbachii was not mentioned (Euro+Med... 2006-2018). The genus is quite common in the southern part of Europe, Turkey, Syria, and Lebanon (Tutin, 1968; Mouterde, 1970; Hedge et Lamond, 1972).

In the course of revision of the genus Cnidium Cusson on the base of a large number of morphological and anatomical characters and a cluster analysis (Lavrova et al., 1987), C. silaifolium was shown to be distant from the type species $C$. monnieri (L.) Cusson ex Jussieu. J. P. Reduron and co-authors (1997) found it reasonable to separate this peculiar plant as a distinct genus, its priority name is Katapsuxis. New combination was proposed: Katapsuxis silaifolia (Jacq.) Reduron, Charpin et Pimenov. A morphological description of Katapsuxis was published by Reduron (2007).
In the molecular phylogenetic analysis (VallejoRoman et al., 2006) the species Katapsuxis silaifolia (as Cnidium silaifolium), Selinum carvifolia (L.) L., S. broteri Hoffmanns. et Link, Cnidiocarpa alaica Pimenov and C. physospermifolia (Albov) Pimenov (as Macrosciadium physospermifolium (Albov) V. Tikhom. et Lavrova) compose a clade with high support, each genus is monophyletic and comprises separate subclades; they are not closely related to Cnidium monnieri and Ligusticum scoticum. In the nrDNA ITS classification of the Apioideae (Downie et al., 2010) L. scoticum is situated in Acronema Clade, whereas Cnidiocarpa, Cnidium, Katapsuxis and Selinum L. are in broad Selineae Clade.

The genus Selinum contains two species distributed in Europe and West Siberia (Tutin, 1968; Pimenov, Ostroumova, 2012) - S. carvifolia and $S$. broteri.

Cnidiocapra Pimenov (1983) was described as containing two species: C. alaica Pimenov from Pamiro-Alai mountains (Middle Asia) and $C$. grossheimii (Manden.) Pimenov (=C. coniifolia (Boiss.) Pimenov) from Turkey and the Caucasus. Later (Pimenov, 2005; Pimenov, Kljuykov, 2010) two Caucasian species: C. alata (M. Bieb.) Pimenov et Kljuykov (= Ligusticum alatum M. Bieb.), C. physospermifolia (=Ligusticum physospermifoium Albov), and a new Caucasian species C. rhodopetala Pimenov et Kljuykov were added. The center of diversity is the Caucasus.

While the plants of the Umbelliferae are easily recognizable (especially the subfamily Apioideae, which includes the genera under consideration), the circumscription of its genera was disputed for centuries and is far from being resolved today. There are more than 300 nomenclatural combinations in the rank of species in Ligusticum, more than 200 combinations in Selinum and more that 70 ones in Cnidium (International Plant Name Index, 2018), and most of these combinations are out of use now.

Hand (2011) probably followed Leute (1970) and used a broad concept of the genus Selinum; he regarded the genera Cnidiocarpa, Kadenia Lavrova et V. N. Tikhom., Katapsuxis, and Cnidium as synonyms of Selinum in contravention of morphological and molecular data. 
The nomenclature of Katapsuxis and Cnidiocarpa is connected with the genera Cnidium, Ligusticum, and Selinum. Detailed morphological descriptions of Katapsuxis, Selinum, Cnidiocarpa, Ligusticum scoticum, Cnidium monnieri were recently published by Pimenov (1983), Lavrova et al. (1983), Castroviejo (2003), Reduron (2007), Pimenov, Kljuykov (2010); Pimenov, Ostroumova (2012), Ostroumova et al. (2016). The great bulk of data concerning the species of middle Europe was published by Thellung (1926). We have studied fruit micromorphology, have reinvestigated fruit anatomy of these five genera, and discuss their relationships on the base of new data.

\section{Material and Methods}

Our own field collections and observations were used for all the species under discussion (except Selinum broteri). Most species were cultivated in the Moscow State University Botanical Garden. We also used material from the herbaria B, BP, LE, M, MHA, MW, W, WU, and ZA (acronyms follow Thiers 2008+).

The material studied for fruit micromorphology and anatomy:

Cnidiocarpa alaica: "E. Tajikistan, S slope of Alai ridge, near Kitchik-Karamik, in a swampy place. 24 VIII 1975. Pimenov, 1332” (iso - MW 0593930). BG MSU N 1975-192.

Cnidiocarpa alata: "Azerbaijan, Dzhimi. 11 VIII 1978. Pimenov et al.” (MW 0700194); "Russia, Kabardino-Balkaria. 23 VIII 1988. Kostyleva, Konovalova” (MW 0700163); “Georgia. 20 VII 1973. Pimenov" (MW 0700174).

Cnidiocarpa coniifolia: "GSSR, Bakuriani, Imeretinsky spur, subalpine meadow. 01 VIII 1940. Mandenova" (iso - LE); "Turkey, Ardanuc. 07 VII 1994. Pimenov et al.” BG MSU N 1977-434.

Cnidiocarpa physospermifolia: "Russia, Adyghea, 29 IX 2008. Kuksina” (MW 0700210).

Cnidiocarpa rhodopetala: "Russia, KarachajCherkessia, $\mathrm{h} \approx 2600$ m. 14 VIII 2006. Zernov, Onipczenko, 5549”' (holo - MW 0593933).

Cnidium monnieri: Hort. Bot. Pekin 1999.

Katapsuxis silaifolia var. silaifolia: "Flora Italica exiccata, Hirpinia - Abellinum (Avellino), in silvis caesis castanearum montis Montenergina, 800$1000 \mathrm{~m}$, solo siliceo, flor. 04 VII 1911, fruct. 18 VIII 1911. G. Pellanda (seeds)" (MW 0785203); "Flora Romaniae exiccata, Transsilvania, destr. Turda, in declivibus apricis ad antrum "Sura Balichi" 480 m; "Firida lui Anton"; "600 m in fissure"; "cheia Turzii, solo calc. 30 VII 1938. Nyarady” (MW 0785198);
"Central Greece, Nomos: Viotias; Mountain: Parnassos, to N-NW of Arachova, slope of SW-facing, Abies forest, near the road, 1539 m, 28 VI 2012. Zakharova, U. Ukrainskaja, 5" (MW 0785199); "Bulgaria, In graminosis et pratis supra Gara Zemen, solo calc. 9 VII 1933. Kitanov" (SOM); "Rodopi Mts., Smolyabsko, Usoikovitsa, limestone cliffs. 2 VIII 1947. Stoyanov" (SOM); "Rodopi Mts., Smolyabsko, Turka. 4 VIII 1947. Stoyanov" (SOM).

Katapsuxis silaifolia var. orientale: "NE Turkey, A8, Erzurum, the valley of the river Tortum, $14 \mathrm{~km} \mathrm{~S}$ of Uzundere. 08 VII 1994. Pimenov et al., 412" (MW); "Armenia turcica. Egin: Kyb-MagharaDagh. 05 VII 1890. Sintenis, 235” (W); “Anatoliae orient. Amasia: in montis Ak-Dagh, regicue alpine, 16-1200 m. 04 VIII 1889. Bornmuller, 379" (W 1898-10529); “Turkey, prov. Sinop: Gerse-Boyabat, Pynus silvestris-Fagus forest, 1200 m. 07 IX 1954. Davis, Polunin, 25021" (W1972-07213); “Turkey, C5, Icel, Toros Daglari, near Camliyayla. 18 VIII 1996. Pimenov et al., T 96-140" (MW 0744521); "Turkey, B2, Izmir, near Kemal-Pasa, Nif Dag, northern slope, 600 m. 14 VIII 1996. Pavlov et al., T 96-12" (MW 0744522).

Katapsuxis silaifolia var, reichenbachii: "Planta Bulgaricae exiccatae. M. Konjova-Planina: in saxosis calcare's declivibus cacuminis Bandera, 1100 m. 05 VIII 1952. Kitanov" (LE; MW 0785196); "Thessalia: Monts Olympos, in declivibus orientalibus iter refugium A et Hagios Dionysos substr. calc., 1200-1500 m. 28 VII 1970. Rechinger 38898" (W 1981-07577); "Croatia Biokovo. 8 VI 1956. Domac" (ZA). "Croatia, Fl. exs. Austro-Hung. N 117, Dalmatia. In saxosis ad pedem montis Biokovo ad Macarscam [no date]. Pichler" (MW 0785197); "FYR Macedonia, pl. Nidže, Bela Reka. 8 VIII 1937. Horvat" (ZAHO).

Ligusticum scoticum: BG MSU N 1999-029.

Selinum carvifolia: BG MSU N 2009-037; "Russia, Moscow reg., Sharapova Okhota, Kljuykov"; "Russia, Tambov reg." (MW 0457690); "Russia, Kursk reg." (MW 0457694); "Russia, Nizhegorodskaya reg." (MW 0457701).

Leaf segments of Katapsuxis silaifolia were measured on 500 specimens from the above mentioned herbaria.

SEM investigations were carried out with a CamScan S-2 (accelerating voltage $15-20 \mathrm{kV}$ and working distance $56 \mathrm{~mm}$ ), at magnification of 15$3000 \times$. Dry fruits were placed on aluminum stubs and sputter-coated with gold or gold-palladium to a thickness of ca. $25 \mathrm{~nm}$. For anatomical investigation, fruits were softened in hot water or 
in glycerol-alcohol-water; free-hand sections were processed with phloroglucinol-hydrochloric acid and kept in glycerol. Microphotographs were made with the Olympus BX41 microscope and Olympus DP25 camera; the device "RA-4" was used for drawings. Fruit morphology was studied with a stereomicroscope Olympus SZ61 (x45) equipped with the digital camera Olympus.

The glossary to describe the fruit microsculpture (Ostroumova et al. 2010, 2011) was compiled using the most important publication in micromorphology (Barthlott Ehler, 1977; Barthlott, 1981; Al-Eisawi Jury, 1988; Hesse et al. 2009, etc.). The types of pinnatisected leaf segments (the type 1 "Anthriscus sylvestris"; and the type 2 "Xanthoselinum alsaticum") were proposed by Pimenov and Ostroumova (2012).

\section{Results}

\section{Fruit morphology and anatomy}

Cnidiocarpa alaica: mericarps elliptic, oblongelliptic or ovate, $4.0-4.5 \mathrm{~mm}$ long, $1.5-2.2 \mathrm{~mm}$ wide; terete or slightly compressed dorsally; all primary ribs equal, narrowly winged; calyx teeth obsolete; stylopodia long-conical; stylodia long (1.4-1.6 mm), recurved; exocarp cells small; commissure narrow; cells with lignified pitted walls are located in the bases of ribs; vascular bundles compact, situated in the middle parts of ribs; endocarp 1-2-layered of rectangular cells; vittae 2-4 in each furrow, 3-4 on commissural side. Mature seed fills the whole locule. (Fig. 1A; 2A).

Cnidiocarpa alata: mericarps elliptic, ovate, or oblong-elliptic, 3-5 mm long, 2-2.5 mm wide, terete or slightly compressed dorsally; all primary ribs equal, narrowly winged; calyx teeth obsolete; stylopodia long-conical; stylodia long $(1.6-1.8 \mathrm{~mm})$, recurved; exocarp cells small; commissure narrow; solitary cells with lignified pitted walls are located in the bases of ribs; vascular bundles compact, situated in the middle parts of ribs; endocarp 1-2-layered of rectangular cells; vittae 2-4 in each furrow, 4-6 on commissural side. Mature seed fills the whole locule. (Fig. 1B; 2B).

Cnidiocarpa coniifolia: mericarps elliptic, ovate, or oblong-elliptic, 3.5-5.3 mm long, 1.5-1.7 $\mathrm{mm}$ wide, terete or slightly compressed dorsally; all primary ribs equal, narrowly winged; calyx teeth obsolete; stylopodia long-conical; stylodia long $(1.2-1.4 \mathrm{~mm})$, recurved; exocarp cells small; commissure narrow; solitary cells with lignified pitted walls are located in the bases of ribs; vascular bundles compact, situated in the middle parts of ribs; endocarp 1-2-layered of rectangular cells; vittae solitary in each furrow, 2 on commissural side. Mature seed fills the whole locule. (Fig. 1C; 2C).

Cnidiocarpa physospermifolia: mericarps elliptic or oblong-elliptic, 3.2-5.0 mm long, 1.2-1.8 $\mathrm{mm}$ wide; terete; all primary ribs equal, narrowly winged; calyx teeth obsolete; stylopodia longconical; stylodia long $(1.0-1.3 \mathrm{~mm})$, recurved; exocarp cells small; commissure narrow; cells with lignified pitted walls are located in the bases of ribs; vascular bundles compact, situated in the middle parts of ribs; endocarp 1-2-layered of rectangular cells; vittae 2-4 in each furrow, 4-6 on commissural side. Mature seed fills the whole locule. (Fig. 1D; 2D).

Cnidiocarpa rhodopetala: mericarps elliptic or oblong-elliptic, $3.7-3.8 \mathrm{~mm}$ long, $1.2-1.5 \mathrm{~mm}$ wide, terete or slightly compressed dorsally; all primary ribs equal, narrowly winged; calyx teeth obsolete; stylopodia long-conical; stylodia long $(1.5-1.7 \mathrm{~mm})$, recurved; exocarp cells small; commissure narrow; mesocarp consists mainly of cells with lignified pitted walls; vascular bundles compact, situated in the middle parts of ribs; endocarp 1-2-layered of rectangular cells; vittae in mature fruits obsolete. Mature seed fills the whole locule. (Fig. 1E; 2E).

Cnidium monnieri: mericarps ovate or elliptic, 2.2-3.0 mm long, $1.5-1.8 \mathrm{~mm}$ wide, terete or slightly compressed dorsally; all primary ribs equal, winged; calyx teeth obsolete; stylopodia short conical; stylodia short $(0.7-0.8 \mathrm{~mm})$, recurved; exocarp cells small; commissure of medium width, exocarp interrupts at the level of commissural secretory ducts; mesocarp consists mainly of cells with lignified pitted walls; endocarp unilayered of elongated or compressed cells; vascular bundles compact, situated in the middle parts of primary ribs; vittae solitary in furrows, two on commissural side. Mature seed fills the whole locule. (Fig. 1F; 2F).

Katapsuxis silaifolia: mericarps ovate or elliptic, 3.0-4.0 $\mathrm{mm}$ long, $2.0-2.5 \mathrm{~mm}$ wide, terete; all primary ribs equal, narrow-winged; calyx teeth obsolete; stylopodia conical; stylodia long (1.3$2.0 \mathrm{~mm}$ ), recurved; exocarp cells small to large; commissure narrow; cells with lignified pitted walls are located in the bases of ribs; endocarp unilayered of rectangular cells; vascular bundles occupying the whole ribs; vittae solitary in furrows, two on commissural side. Mature seed fills the whole locule. (Fig. 1H; 2G). 
Ligusticum scoticum: mericarps elliptic to oblong, 4-11 mm long, 2.0-3.5 mm wide, terete or slightly compressed dorsally; ribs equal, narrowwinged; calyx teeth prominent, short, triangular; stylopodia short conical; stylodia very short $(0.2-0.5 \mathrm{~mm})$, divergent; exocarp cells large; commissure narrow; mesocarp parenchyma partially disintegrated; cells with lignified pitted walls are located in the bases of ribs; endocarp unilayered of elongated or compressed cells; vascular bundles compact, situated in basal or middle parts of primary ribs; vittae $2-5$ in each furrow, 4-10 on commissural side. Mature seed is situated in the upper part of the locule. (Fig. 1G; 2H).
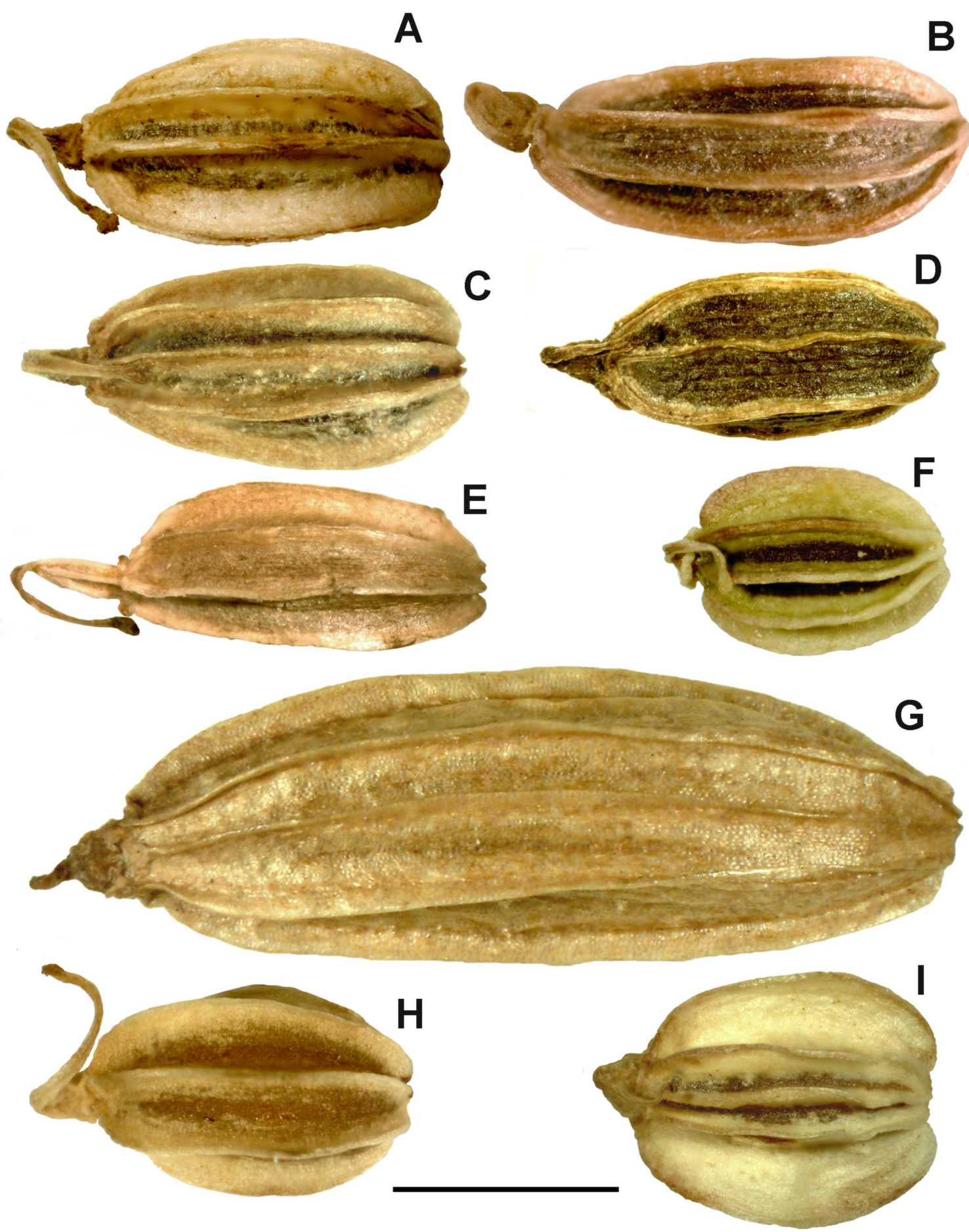

Fig. 1. Mericarps, dorsal view: A - Cnidiocarpa alaica; B - C. alata; C - C. coniifolia; D - C. physospermifolia; E - C. rhodopetala; F - Cnidium monnieri; G - Ligusticum scoticum; H - Katapsuxis silaifolia; I - Selinum carvifolia. Scale bar $=2 \mathrm{~mm}$. 
Selinum carvifolia: mericarps ovate or elliptic, 2.2-4.0 mm long, 2.0-3.5 mm wide, slightly compressed dorsally; ribs unequal, dorsal ribs winged; marginal ribs broadly-winged; calyx teeth obsolete; stylopodia short conical; stylodia short or long $(0.8-1.0 \mathrm{~mm})$, recurved; exocarp cells small;
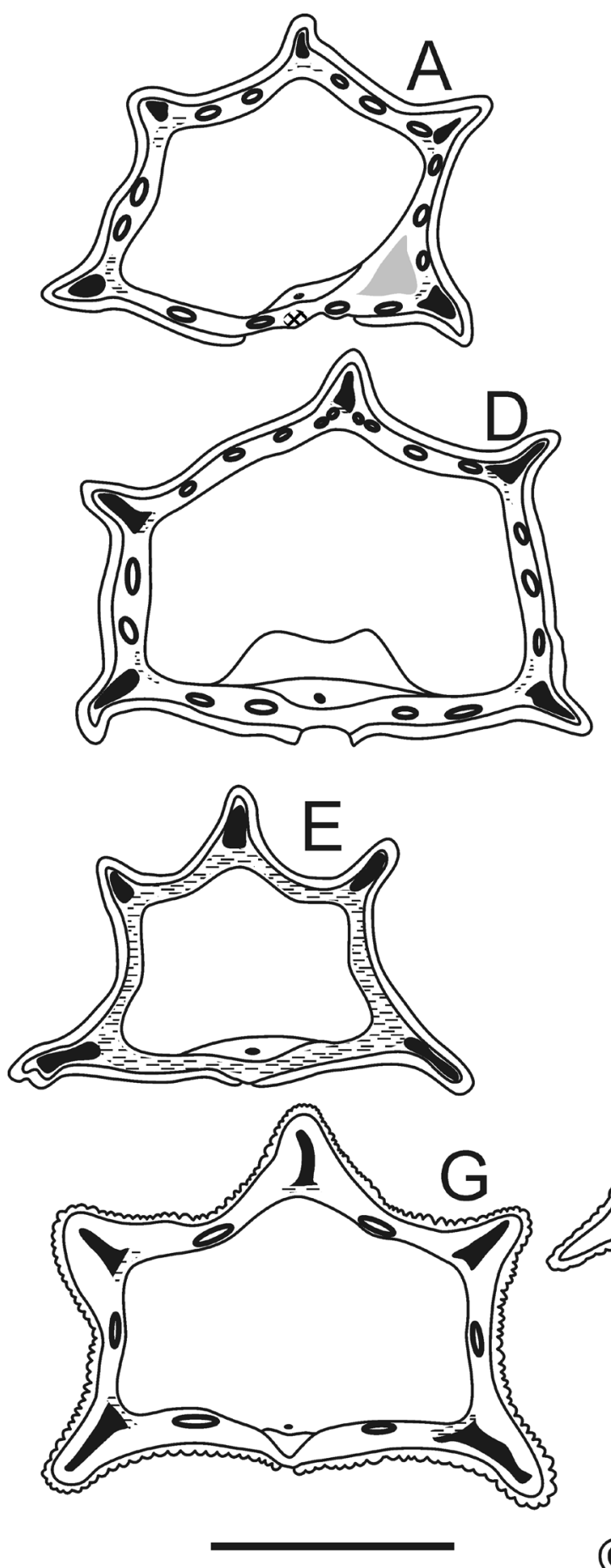

commissure narrow; cells with lignified pitted walls are located in the bases of ribs; endocarp unilayered of elongated or compressed cells; vascular bundles compact, occupying the whole ribs; vittae $1-5$ in each furrow, 4-10 on commissural side. Mature seed fills the whole locule. (Fig. 1I; 2I).
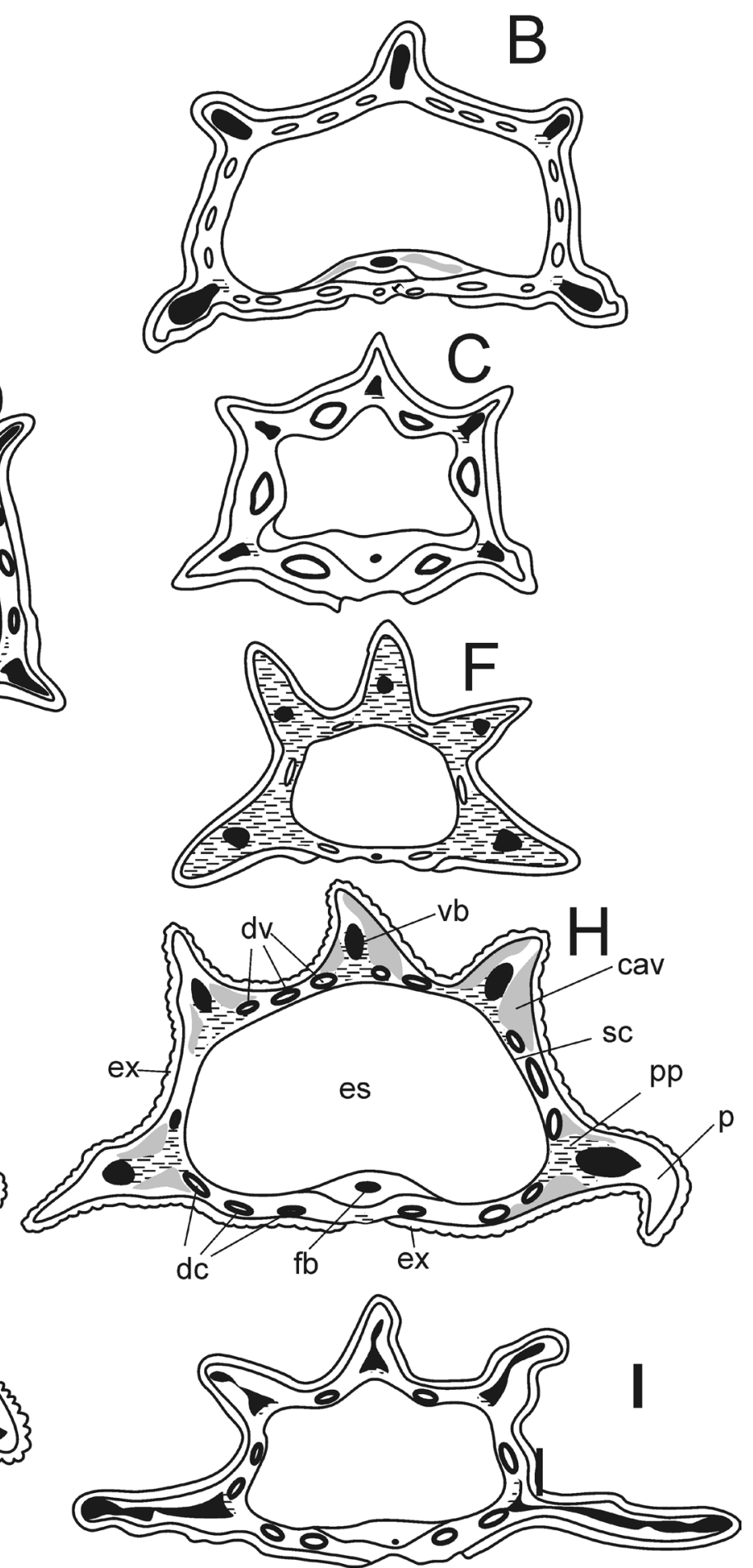

Fig. 2. Mericarp transections, schematic: A - Cnidiocarpa alaica; B - C. alata. C - C. coniifolia; D - C. physospermifolia; E - C. rhodopetala; F - Cnidium monnieri; G - Katapsuxis silaifolia; H - Ligusticum scoticum; I - Selinum carvifolia. Scale bar $=1 \mathrm{~mm}$ (Abbreviations: cav - cavity, dc - commissural secretory duct, dv - vallecular secretory duct, es - endosperm, ex - exocarp, $\mathrm{fb}$ - funicular bundle, $\mathrm{p}$ - parenchyma, $\mathrm{pp}$ - lignified parenchyma with pitted cell walls, sc - seed coat, vb - vascular bundle). Drawing by T. A. Ostroumova, T. V. Lavrova and U. A. Ukrainskaja. 


\section{Fruit micromorphology}

In species under consideration, the rib crests are rather uniform: cell borders are indistinct, surface longitudinally sulcate (except the fruits of Ligusticum scoticum, that are all over covered by uniform cells), cuticle striate. Microsculpture of rib slopes and valleculas is more diverse and is described below. Stomata are absent in the valleculas and presented on rib slopes. Stomata are usually rare, $1-3$ per 1 square $\mathrm{mm}^{2}$, sometimes no stomata are visible on an image of $1 \mathrm{~mm}^{2}$.

Cnidiocarpa alaica: Cell borders indistinct in some areas, surface undulate or foveolatetuberculate; in other areas cell borders distinct, cells arranged at random, isodiametric, borders sunken, outer periclinal walls flat or slightly convex; cuticle striate and rugulate. Stomata rare, cuticle around stomata usual. Epicuticular wax absent. (Fig. 3A; 3B).

Cnidiocarpa alata. Cell borders indistinct in some areas, surface undulate or irregularity rugate, in other areas cell borders distinct, cells arranged at random, isodiametric or elongate, borders sunken, outer periclinal walls flat or slightly convex, cuticle rugulate. Stomata rare, cuticle around stomata usual. Epicuticular wax absent. (Fig. 3C; 3D).

Cnidiocarpa coniifolia. Cell borders mostly indistinct, surface undulate or longitudinally rugate; sometimes on small areas cell borders distinct, cells arranged at random, isodiametric or elongate, borders sunken, outer periclinal walls flat or slightly convex, cuticle rugulate. Stomata rather numerous, cuticle around stomata usual. Epicuticular wax absent. (Fig. 3E; 3F).

Cnidiocarpa physospermifolia: Cell borders indistinct, surface undulate or irregularly rugate, cuticle rugulate. Stomata rare, cuticle around stomata usual. Epicuticular wax absent. (Fig. 3G; $3 \mathrm{H})$.

Cnidiocarpa rhodopetala Cell borders indistinct, surface foveolate-tuberculate, transversely rugate or sometimes with compressed projections; cuticle rugulate. Stomata and epicuticular wax absent. (Fig. 3I, 3J).

Cnidium monnieri. Cell borders indistinct, surface irregularity rugate, cuticle hidden under the rough layer of epicuticular wax. Stomata rare, cuticle around stomata usual. (Fig. 3K; 3L).

Katapsuxis silaifolia. Cell borders distinct, cells arranged at random, isodiametric, borders sunken, outer periclinal walls convex, dome-shaped, papillose, or with conical projections, cuticle rugulate or striato-knotted. Stomata few or absent. Epicuticular wax absent. (Fig. 4A; 4B).

Ligusticum scoticum. Cell borders distinct, cells large $(30-60 \mu \mathrm{m})$, borders sunken, outer periclinal walls convex, cuticle rugulate, wax absent. Stomata rather numerous. Epicuticular wax present on rib crests only, rough and thin. (Fig. 4C; 4D).

Selinum carvifolia. Cell borders indistinct in some areas, surface undulate, irregularity rugate, or transversally rugulate; in other areas cell borders distinct, cells arranged at random, isodiametric, borders sunken, outer periclinal walls flat, convex or with compressed projections; cuticle rugulate or sparsely striate. Stomata rare, cuticle around stomata usual. Epicuticular wax absent. (Fig. 4E; 4F).

\section{Discussion / Taxonomy}

The fruits of the five genera have similar appearance, that was a source of numerous confusions and nomenclature changes: mericarps glabrous, ovate or elliptic, terete or slightly compressed dorsally, with conspicuous winged ribs, narrow commissure, endosperm with flat on the commissural side. Katapsuxis, Selinum and Cnidiocarpa have a lot of common in their habit: glabrous perennial polycarpic herbs with short horizontal rhizomes and several large basal leaves. In the dense plant communities they have usually one flowering/fruiting stem, and in environment with low competition in wild or in botanical garden the individuals become large and multistemmed. Leaves ovate or triangular in outline, 3-4-pinnatisect, first order segments with petiolules.

On the base of morphological and molecular data we regard Katapsuxis, Selinum and Cnidiocarpa as related, but separate genera, which are rather distant from Ligusticum s. str. and Cnidium s. str.

\section{Key for the genera}

1. Annual plants without basal leaf rosette; stems pubescent, especially in nodes and under umbels; bracts and bractlets ciliate, leaves pubescent on the upper side; mericarp ribs equal, narrow winged, stylopodia short-conical, styles short; commissure of medium width, mesocarp composed mainly of parenchyma cells with lignified pitted walls

\section{Cnidium monnieri}

+ Perennial polycarpic plants with glabrous stems, several large basal leaves, bracts and bractlets glabrous, leaves glabrous; stylopodia long- or shortconical, styles long or short; mericarp ribs equal or unequal, narrow or broadly winged, commissure 
narrow, parenchyma cells with lignified pitted walls absent, located at the rib bases, or (Cnidiocarpa rhodopetala) fill the whole mesocarp
2. Leaves 2-ternate, ultimate segments broadly ovate, dentate; calyx teeth present, triangular, styles very short; mericarp ribs equal, narrow winged; seed

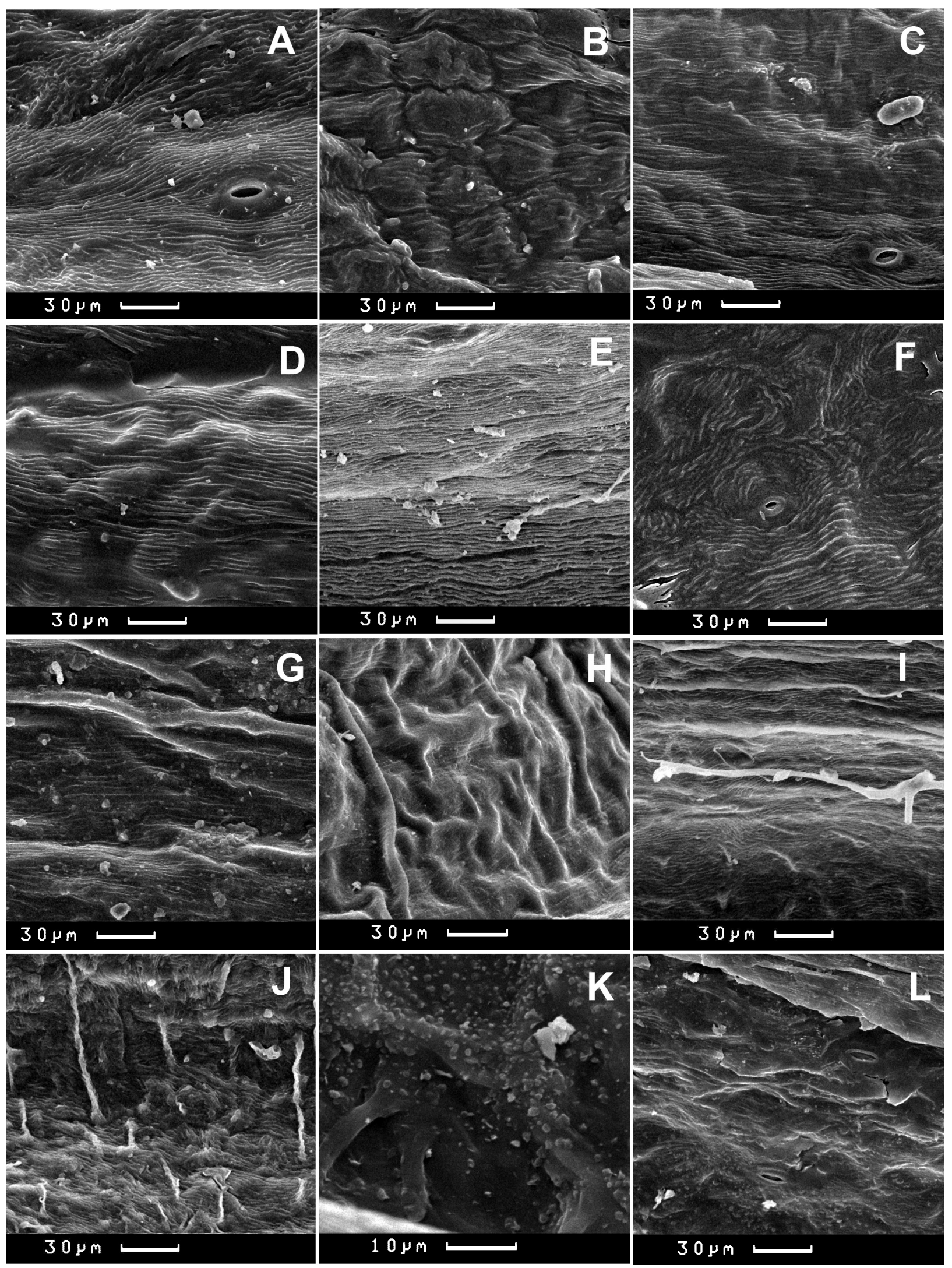

Fig. 3. Fruit micromorphology: A, B - Cnidiocarpa alaica; C, D - C. alata; E, F - C. coniifolia; G, H - C. physospermifolia; I, J - C. rhodopetala; K, L - Cnidium monnieri. 
occupies the upper part of mericarp cavity; exocarp cell borders conspicuous, cells large $(>35 \mu \mathrm{m})$, convex

Ligusticum

+ Leaves 2-4-pinnate, ultimate segments pinnatisect, if entire and dentate, they are elongate or linear; calyx teeth inconspicuous, styles long, exocarp cells $<35 \mu \mathrm{m}$, cell borders conspicuous or not; seed occupies the whole mericarp cavity ...... 3

3. Stem hollow; ultimate leaf segments entire and dentate, or pinnatisect of "Anthriscus type"; upper leaf sheaths slightly inflate; stylopodia long-conical; mericarp vascular bundles compact, situated in the middle parts of ribs, parenchyma cells with lignified pitted walls fill the whole mesocarp or located at the rib bases

Cnidiocarpa

+ Stems solid, ultimate leaf segments pinnatisect of "Xanthoselinum type" or ( $K$. silaifolia var. reichenbachii) linear; upper leaf sheaths narrow, stylopodia long- or short-conical, mericarp vascular bundles stretched along the whole ribs; parenchyma cells with lignified pitted walls absent or solitary ...

4. Stems under umbels canaliculate; stylopodia conical, mericarps terete, ribs equal, narrow-winged, vallecular secretory ducts solitary, exocarp cell borders conspicuous, periclinal walls dome-shaped, papillose, or with conical projections

Katapsuxis

+ Stems under umbels alate, stylopodia shortconical, mericarps slightly compressed dorsally, dorsal ribs winged, marginal ribs broadly winged, secretory ducts 2-4 in each vallecula, exocarp cell borders usually inconspicuous, fruit surface undulate or rugate

Selinum

CNIDIOCARPA Pimenov, 1983, Bot. Zhurn. 68, 1: 88.

Type: Cnidiocarpa alaica Pimenov.

5 species.

\section{Key for the species of Cnidiocarpa}

1. Ultimate leaf segments of "Anthriscus type" (pinnatisect with lobes decreasing from base to top)

+ Ultimate segments oblong or lanceolate, entire or with 1-2 notches

2. Stems alate in the upper part, petiolules of basal leaf segments $>10 \mathrm{~mm}$, petals white (sometimes light pink in flower buds), parenchyma cells with lignified pitted walls restricted to rib bases, secretory ducts $2-4$ in valleculas

Cnidiocarpa alata
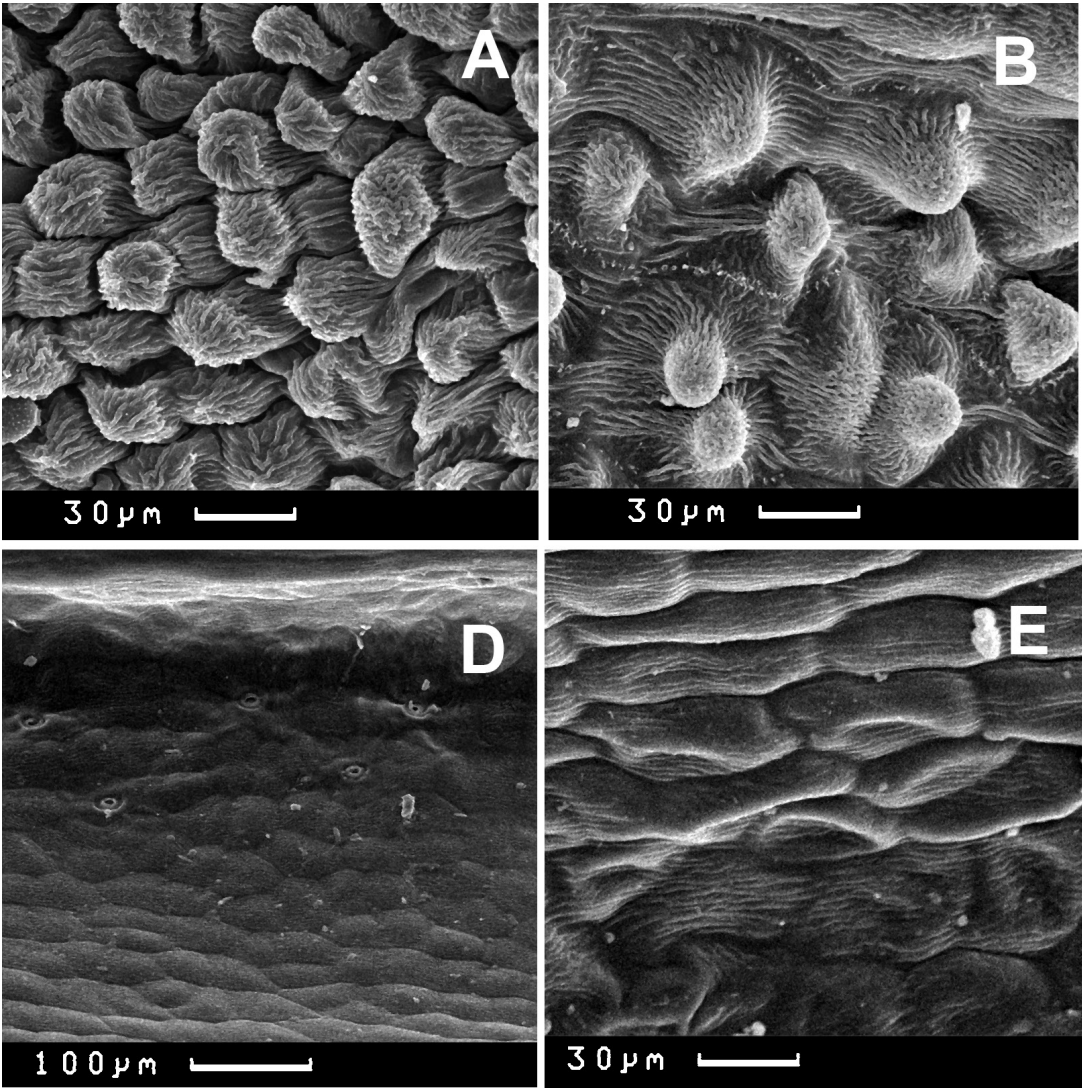
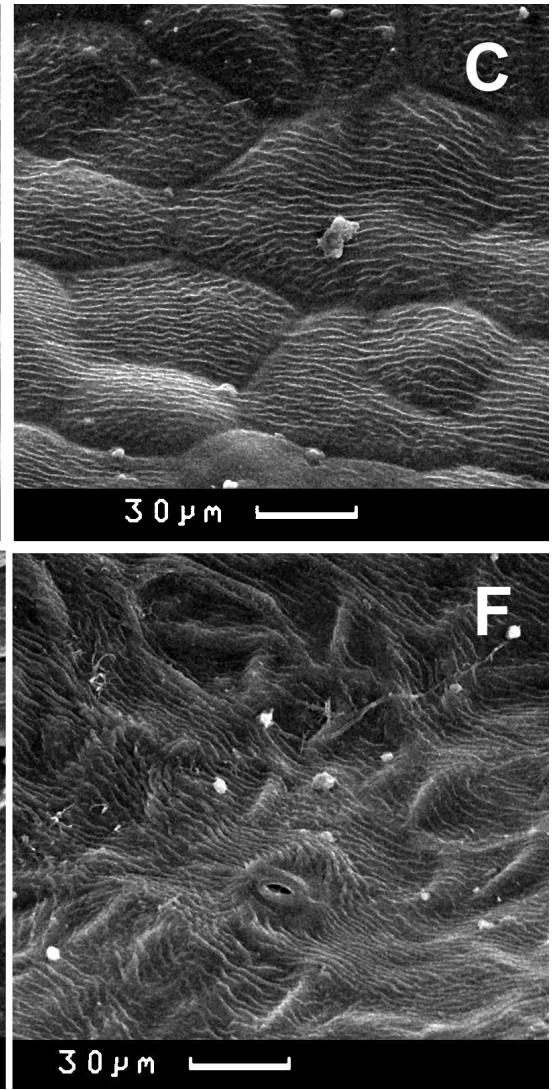

Fig. 4. Fruit micromorphology: A, B - Katapsuxis silaifolia; C, D - Ligusticum scoticum; E, F-Selinum carvifolia. 
+ Stems canaliculate, petiolules of leaf basal segments $5-10 \mathrm{~mm}$, petals pink, mesocarp consists of parenchyma cells with lignified pitted walls, secretory ducts in mature fruits inconspicuous

Cnidiocarpa rhodopetala

3. Basal segments of leaf blade as large or larger than the rest of blade, blades broadly ovate or almost circular in outline, secretory ducts $2-4$ in each vallecula

Cnidiocarpa physospermifolia

+ Basal segments of leaf blade smaller than the rest of blade, secretory ducts solitary or $2-3$ in valleculas

4. Sheaths of middle stem leaves slightly inflate, involucres of 7-11 bracts, involucells of 7-10 bractlets, mericarps 5-6 $\mathrm{mm}$ long, 2-3 $\mathrm{mm}$ wide, vallecular secretory ducts solitary

Cnidiocarpa coniifolia

+ Sheaths of middle stem leaves narrow, involucre absent or of 1-2 bracts, involucells of 2-4 bractlets, mericarps $3-4 \mathrm{~mm}$ long, $1.5-2 \mathrm{~mm}$ wide, secretory ducts $2-3$ in each vallecula

Cnidiocarpa alaica

Cnidiocarpa alaica Pimenov, 1983, Bot. Zhurn. 68, 1: 88, fig. B. (Fig. 1A; 2A; 3A; 3B; 5A).

Type: Tadzhikistan: "Tadzhikistania orientalis, declive australe jugi Alaici, prope pag. Kitschik-Karamyk, in loco paludoso. 24 VIII 1975. Pimenov, 1332" (holo - LE!).

Distribution: Kirghizia, Tadzhikistan.

Cnidiocarpa alata (M. Bieb.) Pimenov et Kjuykov, 2010, Bot. Zhurn. 95, 1: 71. (Fig. 1B; 2B; 3C; 3D; 5B).

$\equiv$ Athamanta alata M. Bieb., 1808, Fl. Taur.Caucas. 1: 214.

$\equiv$ Ligusticum alatum (M. Bieb.) Spreng., 1813, Neue Schr. naturf. Ges. Halle 2, 1 (Pl. Umb. Prodr.): 40.

$\equiv$ Macrosciadium alatum (M. Bieb.) V. N. Tikhom. et Lavrova, 1988, Byull. Moskovsk. Obšč. Isp. Prir. Otd. Biol. 93, 6: 63.

Type: Russia: "In Caucaso subalpino [Ex Caucaso cabardinico] circa acidulam Narzana. 1799, 1803. Marchall von Bieberstein" (holo - LE-Bieb!).

Distribution: Russia (N. Caucasus), Azerbaijan, Georgia, Armenia, Turkey, Iran.

Cnidiocarpa coniifolia (Boiss.) Pimenov, 2005, Bot. Zhurn. 90, 2: 252. (Fig. 1C; 2C; 3E; 3F; 5C).

$\equiv$ Cnidium coniifolium Boiss., 1844, Ann. Sci. Nat. (Paris), sér. 3, Bot. 1 (Pl. Aucher.): 299.

$\equiv$ Selinum coniifolium (Boiss.) Leute, 1970,
Ann. Naturhist. Mus. Wien 74: 508, nom. illeg., non Benth. (1867).

Type: Turkey: "In vallibus ad septentrionem spectantibus regionis mediae Olympi Bithyni [Olympi sylvis]. 1842. Boissier" (holo - G-BOIS!).

= Cnidium grossheimii Manden., 1950, Bot. Mater. Gerb. Bot. Inst. Komarova Akad. Nauk SSSR 13: 171.

三 Cnidiocarpa grossheimii (Manden.) Pimenov, 1983, Bot. Zhurn. 68, 1: 88, fig. A.

Type: Georgia: "Georgia, in viciniis pag. Bakuriani, in brachio Imeretino, pratum subalpinum. 01 VIII 1940. Mandenova" (holo - TBI!; iso - LE!).

Distribution: Georgia, Turkey.

Cnidiocarpa physospermifolia (Albov) Pimenov, 2005, Bot. Zhurn. 90, 2: 254. (Fig. 1D; $2 \mathrm{D} ; 3 \mathrm{G} ; 3 \mathrm{H} ; 5 \mathrm{D})$.

इLigusticum physospermifolium Albov, 1895, Trudy Tiflissk. Bot. Sada 1 (Prodr. Fl. Colch.): 109.

$\equiv$ Macrosciadium physospermifolium (Albov) V. N. Tikhom. et Lavrova, 1988, Byull. Moskovsk. Obšč. Isp. Prir. Otd. Biol. 93, 6: 64.

Type: Russia: "Abchasia, m. Mamdzyschkha, 1900 m, jugum Poev, reg. alp.-subalp., 31 VIII 1894. Albov, 174" (lecto - LE!: designated by G.-H. Leute in Ann Naturhist. Mus. Wien 74: 489 (1970); iso $-\mathrm{G}$ !).

Distribution: Russia (N. Caucasus), Georgia.

Cnidiocarpa rhodopetala Pimenov et Kljuykov, 2010, Bot. Zhurn. 95, 1: 71, fig. 1-2. (Fig. 1E; 2E; 3I; 3J; 5E).

Type: Russia: "Caucasus septentrionalis, Karachaj-Cherkessia, praedium publicum defensum Teberdense, fontes fluminis Azgek, vix infra lacus dextri ad ripam fluminis, $\mathrm{h} \approx 2600 \mathrm{~m}$ supra mare. N4325'12", E41 ${ }^{\circ} 38^{\prime} 48^{\prime \prime} .14$ VIII 2006. Zernov et Onipczenko, 5549" (holo - MW!; iso - LE!).

Distribution: Russia (N. Caucasus).

CNIDIUM Cusson ex Jussieu, 1787, Mém. Soc. Nat. Med. Paris: 280.

Lectotype: C. monnieri (L.) Cusson ex Jussieu.

$4-5$ species.

Cnidium monnieri (L.) Cusson ex Jussieu, 1787, Mém. Soc. Nat. Med. Paris: 280. (Fig. 1F; 2F; 3K; 3L; 5F).

三Selinum monnieri L., 1755, Cent. P1. 1:9.

Type: "In Gallia australi. Monnier [497.11]" (lecto - LINN-Sm).

Distribution: Russia, Mongolia, China, Korea, Vietnam, Laos, Bangladesh, India. 
KATAPSUXIS Raf. 1840, Good Book: 58.

Type: K. cicutaefolium (Villars) Raf. 1840, Good Book: 59. (= Ligusticum cicutaefolium Villars, 1787, in Hist. P1. Dauph. 2: 612, t. 16).

1 species.
Europe (W, S, SE), Asia (SW).

K. silaifolia (Jacq.) Reduron, Charpin et Pimenov, 1997, J. Bot. Soc. Bot. France 1: 99. (Fig. 1H; 2G; 4 A; 4B).

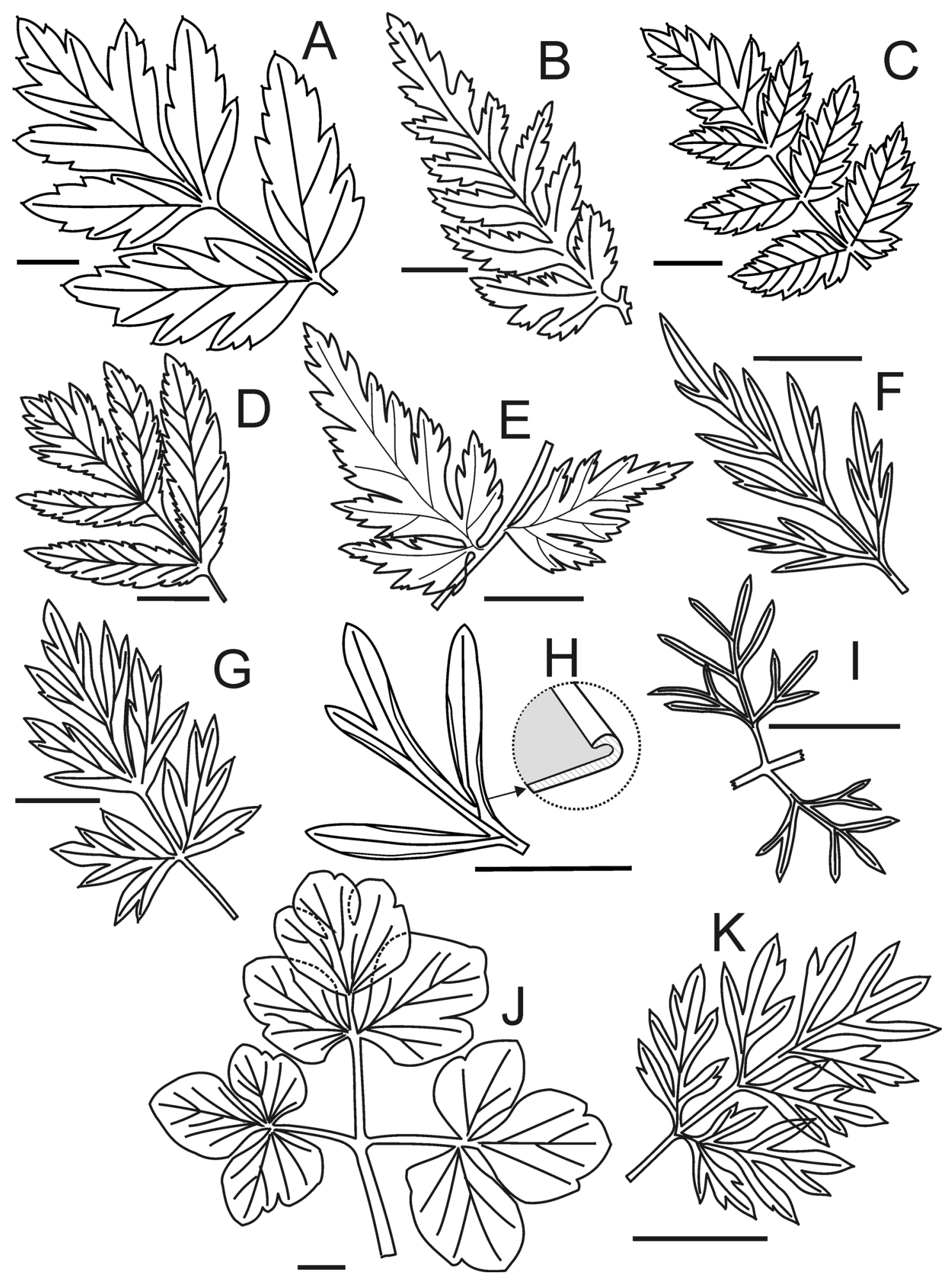

Fig. 5. Leaf segments: A - Cnidiocarpa alaica; B - C. alata; C - C. coniifolia; D - C. physospermifolia; $\mathrm{E}-$ C. rhodopetala; F - Cnidium monnieri; G-I - Katapsuxis silaifolia: $\mathrm{G}$ - var. silaifolia; $\mathrm{H}$ - var. orientale, abaxial side, note revolute margins; I - var reichenbachii; J - Ligusticum scoticum; K - Selinum carvifolia. Scale bars $=1 \mathrm{~cm}$. Drawing by T. A. Ostroumova and T. V. Lavrova. 
$\equiv$ Laserpitium silaifolium Jacq., 1778, in Fl. Austriac. 5: 52, tab. 44.

$\equiv$ Cnidium silaifolium (Jacq.) Simonk., 1886, Enum. Fl. Transsilv.: 259.

$\equiv$ Selinum silaifolium (Jacq.) Beck, 1927, Srpska Kral'ev. Acad. Kn'igha (Fl. Bosn. Herceg. 3) 15: 449.

Type: [Slovenia, Italia] "In collibus saxosis Cartsii in Carniolia, in monte generoso Italiae". Jacquin's specimens with these labels have not been found until now, so Reduron (2007) discussed the probability of designating the image (Jacquin, 1778, tab. 44) as the type.

= Ligusticum cicutaefolium Villars (1787, Hist. P1. Dauph. 2: 612, t. 16).

= Katapsuxis cicutifolia Raf., 1840, Good Book: 59 ("cicutefolia").

Type: [France] "prés de Vif sur la montagne Die er ailleurs" Herbier Villars 929 (GRM).

Distribution: Albania, Bosnia and Herzegovina, Bulgaria, Czech Republic, Croatia, France, Germany, Greece, Italy, FYR Macedonia, Montenegro, Romania, Slovenia, Serbia, Sweden, Switzerland, Turkey, Lebanon, Syria.

Note. As Merrill (1949) found, K. silaifolium (Villars) Raf. corresponds to Ligusticum silaifolium Villars, and the reference to Laserpitium in Rafinesque's book is a misprint. Villars had not ever published the combination "Laserpitium cicutaefolium".

\section{Key for the varieties}

1. Ultimate leaf segments linear, $0.7-1.3 \mathrm{~mm}$ wide var. reichenbachii

+ Leaf segments pinnatifid, ultimate lobes 1-5 mm wide

2. Leaf lobes coriaceous, with revolute margins and obtuse mucronate apex .............. var. orientalis

+ Leaf lobes thin, flat, and acute var. silaifolia

var. silaifolia (fig. 5G).

var. orientalis (Boiss.) Reduron, Charpin et Pimenov, 1997, J. Bot. Soc. bot. France 1: 99. (Fig. $5 \mathrm{H})$.

$\equiv$ Cnidium orientale Boiss., 1844, Ann. Sci. Nat. (Paris), sér. 3, Bot. 1 (Pl. Aucher.): 299.

Type: Turkey: "Asia Minor, Aucher-Eloy 3733" (lecto - G-BOIS, designated by Reduron et al. (1997).

Distribution: Greece, Bulgaria, Bosnia and Herzegovina, Turkey, Lebanon, Syria.

var. reichenbachii (Huter ex Pichler) Ostr. (Fig. $5 \mathrm{I})$. $\equiv$ Cnidium reichenbachii Huter ex Pichler, 1881, in Kerner, Sched. Fl. Exsicc. Austro-Hung. 1: 28.

$\equiv C$. silaifolium (Jacq.) Simonk. var. reichenbachii (Huter ex Pichler) Hayek, 1927, Repert. Spec. Nov. Regni Veg. Beih. 30, 1 (Prodr. Fl. Penins. Balc. 1): 1020.

Type: [Croatia] "Dalmatia, sub rupibus supr. Macarsca. Jun. 1870 Pichler. BOZ, Huter 23177!"

= Selinum silaifolium (Jacq.) Beck ssp. reichenbachii Leute, 1970, Ann. Naturhist. Mus. Wien, 74: 500.

Type: "[Croatia]A. Teyber"(holo-WU0089737!, iso - WU0089737!).

Distribution: Bulgaria, Croatia, Greece, Italy, FYR Macedonia.

LIGUSTICUM L., 1753, Sp. P1.: 250; 1754, Gen. Pl., ed. 5:119.

Type: L. scoticum L.

1 species.

Ligusticum scoticum L., 1753, Sp. P1.: 250. (Fig. $1 \mathrm{G} ; 2 \mathrm{H} ; 4 \mathrm{C} ; 4 \mathrm{D} ; 5 \mathrm{~J})$.

Type: "Ad litora maris in Anglia Suecia. Herb. Clifford, 97, Ligusticum 3" (lecto - BM-Cliff.).

= Ligusticum hultenii Fernald, 1930, Rhodora 32: 7, tab. 1024.

Type: "USA, Nazan Bay, Atka, Alaska. 26 VII 1907. E. C. Van Dyke, 238” (holo - GH).

Distribution: Great Britain, Denmark, Finland, Ireland, Iceland, Norway, Russia, Sweden, Japan, Korea, Canada, USA.

SELINUM L. 1762, Sp. pl., ed. 2: 350, nom. cons.

Lectotype: S. carvifolia (L.) L., typ. cons. (Seseli carvifolia L.) (Hitchcock, Green, 1929; ICNAFP; ING).

2 species. Treated here in a narrow circumscription (Lavrova et al., 1987; Plunkett et al., 2018), the most nomenclatural combinations in Selinum are now regarded as synonyms (e.g. Pimenov, 2017, 2018).

Key for the species

1. Stem in the upper part with winged ribs, all the leaves with similar segments, umbel rays 10-30, styles 2-3 times longer than stylopods

S. carvifolia

+ Stems striate, without wings, the lobes of lower leaves shorter and narrower than in upper leaves, styles slightly longer than stylopods .......S. broteri

Selinum carvifolia (L.) L., 1762, in Sp. pl. ed. 2, 1: 350. (Fig. 1I; 2I; 4E; 4F; 5K). 
三Seseli carvifolia L., 1753, in Sp. pl., ed.1: 260.

Type: Icon.: "Angelica tenuifolia in Rivinus, Ordo Pl. Fl. Pentapet.: 18 (1699)" (lecto - designated by Reduron et Jarvis in Jarvis al. (ed.), Regnum Veg. 127: 87 (1993)).

Distribution: Austria, Belarus, Belgium, Bosnia and Herzegovina, Bulgaria?, Czech Republic, Croatia, Denmark, Estonia, Finland, France, Germany, Great Britain, Hungary, Italy, Latvia, Lichtenstein, Lithuania, Luxemburg, Moldova, Netherlands, Norway, Poland, Romania, Russia, Slovakia, Slovenia, Serbia, Sweden, Switzerland, Ukraine.

Selinum broteri Hoffmanns. et Link, [18201824]. Fl. Portug. 2: 428.

三Selinum carvifolia (L.) L. ssp. broteri (Hoffmanns. et Link) Laínz, 1968, Aportaciones al Cono- cimiento de la Flora Gallega M[adrid] 6: 18 - nisterio de Agricultura 39p.

Type: Syntypes: "Dans la Serra-de-Marao, près de Campeao. Aux environs de Viseu et de Torres vedras selon Brotero". Herbarium specimens not found.

Distribution: France, Portugal, Spain.

Histological structure of its fruit is unknown. Leute (1970) studied immature fruits with 1-2 secretory ducts per vallecula and 4 ducts on commissural side; Arenas Posada et al. (1993) also could not find mature fruits; Castroviejo (2003) published a small image of transection of mature fruit: it resembles $S$. carvifolia, with 1-2 ducts per furrow. According to Vallejo-Roman et al. (2006) S. carvifolia and S. broteri are united in the subclade with high bootstrap.

\section{REFERENCES / ЛИTEPATУPA}

Al-Eisawi D., Jury S. L. 1988. A taxonomic revision of the genus Tordylium L. Bot. J. Linn. Soc. 97: 357-403.

Anthos. Spanish plants information system. 2012-2018. URL: http://www.anthos.es (Accessed 01 November 2018).

Arenas Posada J. A., Garcia Martin F. 1993. Atlas carpologico y corologico de la subfamilia Apioideae Drude (Umbelliferae) en Espana peninsular y Baleares. Ruizia 12: 1-245.

Barthlott, $\boldsymbol{W} .1981$. Epidermal and seed surface characters of plants: systematic applicability and some evolutionary aspects. Nordic J. Bot. 1(3): 345-355.

Barthlott W., Ehler N. 1977. Raster-Elektronenmikroskopie der Epidermisoberflächen von Spermatophyten. Tropische und subtropische Pflanzenwelt 19: 367-467.

Beck Von Mnnnagetta G. 1927. Flora Bosne, Hercegovine i Oblasti Novoga Pazara. Vol. 3. Beograd, Sarajevo, $487 \mathrm{pp}$.

Castroviejo S. (ed.) 2003. Flora iberica. Plantas vasculares de la Península Iberica e Islas Baleares. Vol. X. Araliaceae-Umbelliferae. Real Jardin Botaníco, Madrid, 498 pp.

Downie S. R., Spalik K., Katz-Downie D. S., Reduron J-P. 2010. Major clades within Apiaceae subfamily Apioideae as inferred by phylogenetic analysis of nrDNA ITS sequences. Plant Diversity and Evolution 128: 111-136.

Euro+Med (2006-): Euro+Med PlantBase - the information resource for Euro-Mediterranean plant diversity. URL: http://ww2.bgbm.org/EuroPlusMed/ (Accessed 01 November 2018).

Halacsy E. 1901. Conspectus florae graecae. Vol. 1(3). Leipzig, 577-825 pp.

Hand R. 2011. The Euro+Med treatment of Apiaceae. Willdenowia 41: 245-250.

Hayek A. 1927. Prodromus florae peninsulae Balcanicae. Repert. Spec. Nov. Regni Veg. 30(1): 1-1193.

Hedge I. C., Lamond J. M. 1972. Cnidium Cusson. In: Flora of Turkey and the East Aegean Islands. Vol. 4. Edinburgh University Press, 429-430 pp.

Heller D., Heyn C. C. 1993. Conspectus florae orientalis. An annotated catalogue of the flora of the Middle East. 7. Jerusalem, $53 \mathrm{pp}$.

Hesse M., Halbritter H., Zetter R., Weber M., Buchner R., Frosch-Radivo A., Ulrich S. 2009. Pollen terminology. An illustrated handbook. Wien, N.-Y., 259 pp.

Lavrova T. V., Pimenov M. G., Devyatkova G. N. 1987. The usage of cluster-analysis in the elucidation of the taxonomic relations of species in subtribe Foeniculinae (Umbelliferae) of the flora of the USSR. Bot. Zhurn. (Moscow \& Leningrad) 72(1): 25-38 [In Russian]. (Лаврова Т. В., Пименов М. Г., Девяткова Г. Н. Использование кластер-анализа для выяснения таксономических отношений видов подтрибы Foeniculinae (Umbelliferae) флоры СССР // Бот. журн., 1987. Т. 72, № 1. С. 25-38).

Lavrova T.V., Pimenov M. G., Tikhomirov V. N. 1983. Description and analysis of fruit structure of the Umbelliferae of the tribe Ligusticeae. Byulleten MOIP. Otdel biologicheskiy [Bulletin of Moscow Society of Naturalists Biological series] 88, 2: 107-122 [In Russian]. (Лаврова Т. В., Пименов М. Г., Тихомиров В. Н. Описание и анализ строения плодов зонтичных трибы Ligusticeae // Бюл. МОИП. Отд. биол., 1983. Т. 88, вып. 2. С. 107-122). 
Leute G. H. 1970. Untrersuchungen über der Verwandtschaftkreis der Gattung Ligusticum L. (Umbelliferae). II. Teil. Ann. Naturhistor. Mus. Wien 74: 457-519.

Merrill E. D. 1949. Index rafinesquianum. The plant names published by C. S. Rafinesque with reductions and consideration of his methods, objectives, and attainments. Arnold Arboretum Harvars University, Mass Jamaica Plain, IX +296 pp.

Mouterde P. 1970. Nouvelle flora du Liban et de la Syrie. Vol. 2. Beyrouth, Dar-el-Machreq, 727 pp.

Ostroumova T. A. 2018. Lectotypification of Cnidium reichenbachii (Umbelliferae) and a new combination based on this name. Bot. Zhurn. (Moscow \&. St. Petersburg) 103(1): 111-115.

Ostroumova T. A., Kljuykov E. V., Lavrova T. V. 2016. Taxonomic position of the genus Katapsuxis Raf. and related genera of the Umbelliferae (Apieae). Problems of Botany of South Siberia and Mongolia (15): 316 -320 [In Russian]. (Остроумова T. А., Клюйков Е. В., Лаврова Т. В. Таксономическое положение рода Katapsuxis Raf. среди близких таксонов Umbelliferae (Apieae) // Проблемы ботаники Южной Сибири и Монголии, 2016. № 15. C. 316-320).

Ostroumova T. A., Pimenov M. G., Ukrainskaja U. A. 2010. Micromorphological diversity of hairs and emergences on fruits in the Umbelliferae and its taxonomic value. Bot. Zhurn. (Moscow \&. St. Petersburg) 95(9): 1219-1231 [In Russian]. (Остроумова Т. А., Пименов М. Г., Украинская У. А. Разнообразие микроморфологии волосков и эмергенцев на плодах зонтичных (Umbelliferae) и его таксономическое значение // Бот. журн., 2010. Т. 95, № 9. C. 1219-1231).

Ostroumova T. A., Pimenov M. G., Ukrainskaja U. A. 2011. Fruit micromorphology in the Umbelliferae and its taxonomical significance. In: XVIII International Botanical Congress (Melbourne, Australia, 23-30 July 2011). Melbourne, 562-563 pp.

Pichler 1881. 117. Cnidium Reichenbachii Huter. In: Schedae ad floram exsiccatam Austro-Hungaricam. Ed. A. Kerner. Vol. 1. Wien, 28 p.

Pimenov M. G. 1983. Cnidiocarpa, a new genus of the family Umbelliferae. Bot. Zhurn. (Moscow \& St. Petersburg) 68(1): 86-89 [In Russian]. (Пименов М. Г. Сnidiocarpa - новый род семейства Umbelliferae // Бот. журн., 1983. T. 68 , № 1. C. 86-89).

Pimenov M. G. 2005. Taxonomical additions and corrections in the genus Cnidiocarpa (Umbelliferae). Bot. Zhurn. (Moscow \& St. Petersburg) 90(2): 250-256 [In Russian]. (Пименов М. Г. Таксономические дополнения и изменения по роду Cnidiocarpa (Umbelliferae) // Бот. журн., 2005. Т. 90, № 2. С. 250-256).

Pimenov M. G. 2017. Updated checklist of Chinese Umbelliferae: nomenclature, synonymy, typification, distribution. Turczaninowia 20, 2: 106-239. DOI: 10.14258/turczaninowia.20.2.9

Pimenov M. G. 2018. Updated checklist of Chinese Umbelliferae: nomenclature, synonymy, typification, distribution. Supplementum. Turczaninowia 21, 1: 113-123. DOI: 10.14258/turczaninowia.21.1.10

Pimenov M. G., Kljuykov E. V. 2010. A new species and a new combination in the genus Cnidiocarpa (Umbelliferae). Bot. Zhurn. (Moscow \& St. Petersburg) 95(1): 70-76 [In Russian]. (Пименов М. Г., Клюйков Е. В. Новый вид и новая комбинация в роде Cnidiocarpa // Бот. журн., 2010. Т. 95, № 1. С. 70-76).

Pimenov M. G., Leonov M. L. 1993. The genera of the Umbelliferae. Royal Botanic Gardens Kew, U. K., 156 pp.

Pimenov M. G., Ostroumova T. A. 2012. Umbelliferae of Russia. KMK Scientific Press, Moscow, 477 pp. [In Russian]. (Пименов М. Г., Остроумова Т. А. Зонтичные (Umbelliferae) России. М.: КМК, 2012. 477 с.).

Plunkett G. M., Pimenov M.G., Reduron J.-P., Kljuykov E. V., Van Wyk B.-E., Ostroumova T. A. et al. 2018. Apiaceae. In: The Families and Genera of Vascular Plants. Ed. K. Kubitzki. Vol. 15. Springer International Publishing AG, 9-206 pp.

Rafinesque C. S. 1840. The good book and amenities of nature. Philadelphia, Eleutherium of Knowledge, 84 pp.

Reduron J.-P. 2007. Ombellifère de France. 3. Bulletin de la Société Botanoque du Centre-Ouest, Nouvelle Série. Numéro special 28: 1-584.

Reduron J.-P., Charpin A., Pimenov M. 1997. Contribution à la nomenclature générique des Apiaceae (Ombellifères). J. Bot. Soc. bot. Fr. 1: 91-104.

Schischkin B. K. 1950. Cnidium Cuss., Selinum L., Ligusticum L. In: Flora SSSR [Flora of USSR]. Vol. 16. Publishers of Academy of Sciences of URSS, Moscow, Leningrad, 549-563, 566-576 pp. [In Russian]. (Шиикин Б. К. Жгун-корень - Cnidium Cuss., Гирча - Selinum L., Лигустикум - Ligusticum L. // Флора CCCP. Т. 16. M.-Л.: Изд-во АН СССР, 1950. С. 549-563, 566-576).

Simonkai L. 1886. Enumeratio florae transilvanicae vesiculosae critica. Budapest, 678 pp.

The International Plant Names Index. 2012-2018. URL: http://www.ipni.org (Accessed 01 November 2018).

Thellung A. 1926. Umbelliferae. In: Illustrierte Flora von Mittel-Europa. Ed. G. Hegi. J. F. Lehmanns Verlag, München, 5(2): 926-1537.

Thiers B. 2008+ [continuously updated]. Index Herbariorum: A global directory of public herbaria and associated staff. New York Botanical Garden's Virtual Herbarium. URL: http://sweetgum.nybg.org/science/ih (Accessed 01 November 2018). 
Tutin T. G. 1968. Cnidium Cuss., Selinum L., Ligusticum L. In: Flora Europaea. Vol. 2. Eds. G. Tutin, V. H. Heywood, N. A. Burges, D. M. Moore, D. H. Valentine, S. M. Walters, D. A. Webb. Cambridge University Press, 355-356 pp.

Valiejo-Roman K. M., Shneyer V. S., Samigullin T. H., Terentieva E. I., Pimenov M. G. 2006. An attempt to clarify taxonomic relationships in "Verwandtschaftkreis der Gattung Ligusticum" (Umbelliferae-Apioideae) by molecular analysis. Pl. Syst. Evol. 257: 25-43. 